\title{
Dual inhibition of EGFR and MET induces synthetic lethality in triple-negative breast cancer cells through downregulation of ribosomal protein $\mathrm{S6}$
}

\author{
YONG WEON YI ${ }^{1,2^{*}}$, KYUSIC YOU ${ }^{1 *}$, EDWARD JEONG BAE ${ }^{1,3}$, \\ SAHNG-JUNE KWAK ${ }^{4}$, YEON-SUN SEONG ${ }^{1,2,4}$ and INSOO BAE ${ }^{1,2}$
}

${ }^{1}$ Department of Nanobiomedical Science and BK21 PLUS Research Center for Regenerative Medicine, Dankook University, Cheonan, Republic of Korea; ${ }^{2}$ Department of Oncology, Lombardi Comprehensive Cancer Center, Georgetown University Medical Center; ${ }^{3}$ Department of Nursing and Health Studies, Georgetown University, Washington, DC, USA; ${ }^{4}$ Department of Biochemistry, College of Medicine, Dankook University, Cheonan, Republic of Korea

Received February 25, 2015; Accepted April 9, 2015

DOI: 10.3892/ijo.2015.2982

\begin{abstract}
Triple-negative breast cancer (TNBC) exhibits innate resistance to the EGFR inhibition despite high level expression of EGFR. Recently, we found that the proliferation of basal-like (BL) subtype TNBC cells is synergistically inhibited by combination of EGFR and PI3K/AKT inhibitors. On the contrary, TNBC cells of mesenchymal stem-like (MSL) subtype are resistant to these combinations. To identify potential synthetic lethal interaction of compounds for treatment of MSL subtype TNBC cells, we performed MTT screening of MDA-MB-231 cells with a small library of receptor tyrosine kinase inhibitors (RTKIs) in the presence of gefitinib, an EGFR inhibitor. We identified MET inhibitors as potent RTKIs that caused synthetic lethality in combination with gefitinib in MDA-MB-231 cells. We demonstrated that combination of a MET inhibitor SU11274 with various EGFR inhibitors resulted in synergistic suppression of cell viability (in MTT assay) and cell survival (in colony formation assay) of MSL subtype TNBC cells. We further demonstrated that SU11274 alone induced G2 arrest and gefitinib/SU11274 combination sustained the SU11274-induced G2 arrest in these cells. In addition, SU11274/gefitinib combination synergistically reduced the level of ribosomal protein S6 (RPS6) in MSL subtype TNBC cells. In addition, knockdown of RPS6 itself, in both HS578T and MDA-MB-231, markedly reduced the proliferation of these cells. Taken together, our data suggest that dual targeting of EGFR and MET inhibits
\end{abstract}

Correspondence to: Dr Yeon-Sun Seong, Department of Biochemistry, College of Medicine, Dankook University, 119 Dandae Ro, Dongnam Gu, Cheonan, Chungnam 330-714, Republic of Korea E-mail: seongys@dankook.ac.kr

${ }^{*}$ Contributed equally

Key words: triple-negative breast cancer, epidermal growth factor receptor, mesenchymal-epithelial transition factor, synthetic lethality, ribosomal protein S6 degradation the proliferation of MSL subtype TNBC cells through downregulation of RPS6.

\section{Introduction}

According to cancer statistics 2014, breast cancer is the top leading cancer in incidence (232,340 cases in USA) with the second highest mortality rate (39,620 death in USA) in women in the United States (1). Triple-negative breast cancer (TNBC), comprising $10-20 \%$ of all breast cancers, is a subgroup of breast cancer showing diverse and heterogeneous features with lack of estrogen receptor (ER) and progesterone receptor (PR) expression as well as human epidermal growth factor receptor 2 (HER2) amplification $(2,3)$ and is inadequate to established hormonal therapy and/or HER 2 targeted therapy due to the lack of these proteins (4). The TNBC shows poor prognosis due to aggressive biological behavior of tumors as well as earlier involvement of distant metastasis (5). No proven optimistic therapies against TNBCs are established yet and the development of new method on the basis of the weak points of TNBCs is needed (6).

Epidermal growth factor receptor (EGFR) is a member of membrane anchored receptor tyrosine kinase ERBB/HER family comprising of EGFR, HER2, HER3 and HER4 $(7,8)$. The EGFR in normal cells is essential for cell proliferation and survival. Aberrant activation of EGFR by copy number amplification, protein overexpression or point mutation is closely related with unregulated proliferation, malignant transformation, invasion, metastasis and resistance to apoptosis of cancer cells $(7,8)$. Up to $70-80 \%$ of metastatic breast cancers shows overexpression of EGFR, but without significant association of HER2 overexpression $(9,10)$. EGFR was found to be expressed at a high level in $\sim 50 \%$ of TNBCs and in $~ 70 \%$ of basal-like breast cancers $(11,12)$. Among the groups of TNBC classified by Lehmann et al, basal-like 2 (BL2) and mesenchymal stem-like (MSL) subtypes show active EGFR signaling (2). More than $50 \%$ of MSL type TNBC is comprised of basallike features according to intrinsic subtype (13). The germline mutations of BRCA1 and early onset of TNBC is also associ- 
ated with EGFR activation in breast cancers (14,15). Along with cytokeratin 5/6 as a marker of basal-like breast cancers, the EGFR expression is a marker of poor prognosis regardless of the expression of ER or PR $(12,14,16-18)$. Nevertheless, the results from clinical trials with anti-EGFR combined with platinum or other neoadjuvant agents revealed disappointing results (19-21).

Gefitinib (Iressa) is an orally administrable anticancer agent against EGFR kinase and shows efficacies against various cancers with EGFR activation including breast, lung, colon and other cancers (22-24). Although gefitinib has effects on EGFR activated cancer cells, apparently most TNBC cells with elevated level of EGFR exhibit resistance to EGFR inhibitor treatment. Previously, we found that combination of gefitinib and PI3K/AKT pathway inhibitors synergistically inhibit subsets of TNBC cells in vitro (25). On the contrary, regardless of high level expression of EGFR, TNBC cells in MSL subtype including HS578T, MDA-MB-231, and MDA-MB-436 are relatively resistant to these combinations (25). Receptor tyrosine kinase crosstalk, providing surrogate or redundant pathways of cell survival against kinase targeted therapy, is one of the mechanisms of drug resistance (26-31). As an attempt to identify potential receptor tyrosine kinase inhibitors (RTKIs) which induce synthetic lethality in the presence of gefitinib, we performed an MTT screening in MDA-MB-231 cells. We further characterized a MET (mesenchymal-epithelial transition factor) inhibitor SU11274 as a synthetic lethal agent with gefitinib in MSL subtype TNBC cells.

\section{Materials and methods}

Cell culture and reagents. Reagents for cell culture were purchased from Invitrogen (Carlsbad, CA, USA), Lonza (Basel, Switzerland), or Cellgro (Manassas, VA, USA). HS578T, MDA-MB-231, and MDA-MB-436 were obtained from the Tissue Culture Shared Resource of Georgetown University Medical Center and maintained in the Dulbecco's modified Eagle's medium (DMEM) (Lonza) containing 10\% heat inactivated fetal bovine serum (Omega Scientific, Inc., Tarzana, CA, USA) and $100 \mathrm{U} / \mathrm{ml}$ penicillin/streptomycin (Lonza). SUM149PT was maintained according to the manufacturer's recommendation (Asterand, Detroit, MI, USA). The viability of cultured cells was monitored by the trypan blue dye exclusion method using the Luna Automated Cell Counter (Logos Biosystems, Gyunggi-Do, Korea). Receptor tyrosine kinase inhibitors were purchased from the following sources: AEW541 from Cayman Chemical (Ann Arbor, MI, USA); AG1024 from Enzo Life Sciences (Farmingdale, NY, USA); BMS-754807 and OSI-906 from MedKoo Biosciences (Chapel Hill, NC, USA); ABT-869, AV-951, BAY 73-4506, BMS-536924, BMS-599626, brivaninb, cediranib, CYC116, E-7080, ENMD-2076, GSK1838705A, GSK1904529A, JNJ-38877605, LDN193189, MGCD265, motesanib, MP-470, NVP-TAE684, OSI-930, PF-2341066 (crizotinib), PHA-665752, SB431542, SB525334, SU11274, Tie2 kinase inhibitor, XL184, and XL880 from Selleck Chemicals (Houston, TX, USA); axitinib, dovitinib, gefitinib, GW-2580, lapatinib, lestaurtinib, masitinib, pazopanib, sorafenib, sunitinib, tandutinib, vandetanib, and vatalanib from LC Labs
(Woburn, MA, USA). Genistein and MG132 was purchase from Sigma (St. Louis, MO, USA). Stock solutions of compounds were made in dimethyl sulfoxide (DMSO) and stored at $-20^{\circ} \mathrm{C}$ in small aliquots.

Synthetic lethal screening. MDA-MB-231 cells (2,500 cells/ well) in 96-well plates were treated with increasing amount of gefitinib and increasing amount of RTKIs in duplicates in a 6x5 matrix (Fig. 1A). In an initial screening, the highest concentration of RTKIs was $10 \mu \mathrm{M}$. The highest concentrations of RTKIs were reduced when significant reduction of cell viability was observed in single agent treatments. The synergism was determined by calculating classification index (CI) with equation of $A x B / A B$, where $A$ and $B$ are the cell viability with individual agent and $A B$ is the cell viability with the combination (32). We further indexed as follows: strong synergism as index 3 when the $\mathrm{CI}>1.3$ at $>5$ combination points; medium synergism as index 2 when the $\mathrm{CI}>1.3$ at 3 or 4 combination points; weak synergism as index 1 when the $\mathrm{CI}>1.3$ at 1 or 2 combination points. Cell viability was determined at $\sim 72 \mathrm{~h}$ after treatment of compounds by MTT (3-(4,5-dimethylthiazol-2-yl)-2,5-diphenyltetrazolium bromide) assay as described previously except for using $4 \mathrm{mg} / \mathrm{ml}$ of MTT solution $(25,33)$.

Clonogenic cell survival assay. Cells were subcultured into 6-well plates with appropriate densities: 500-1,000 cells/well for HS578T and 3,000 cells/well for MDA-MB-231. The day after subculture, the cells were treated with indicated concentrations of compounds for $24 \mathrm{~h}$, and then the cells were supplemented with fresh normal growth media without compounds. The cells were further cultured for 10-14 days after treatment with replacement of fresh normal growth media twice per week. The survived colonies were stained as described previously (34). After intensive washing, the images of colonies were captured by scanner. The relative number of colonies was determined as follows: crystal violet stain of colonies was solubilized by solubilization buffer [1:1 mixture (v/v) of $0.1 \mathrm{M}$ sodium phosphate $\left(\mathrm{NaH}_{2} \mathrm{PO}_{4}, \mathrm{pH} 4.5\right)$ and ethanol] and the observance of solubilized crystal violet was measured by ELx808 microplate reader (BioTek, Winooski, VT, USA).

Western blot analyses and antibodies. Western blot analyses were performed as described previously (25). Antibodies used in this study were as follows: MET (sc-161), ERK1 (sc-94), and PARP (sc-7150) from Santa Cruz (Santa Cruz, CA, USA); p-EGFR (Y1068) (\#2237), EGFR (\#4405), p-MET (Y1234/Y1235) (\#3123), phospho-AKT (Ser473) (\#9271), AKT (\#9272), p-ERK1/2 (T202/Y204) (\#4370), p-p70 S6K (T389) (\#9205), p70 S6K (\#9202), p-S6 (S235/S236) (\#4856), S6 (\#2217) and XIAP (\#2045) from Cell Signaling (Danvers, MA, USA); $\alpha$-tubulin, $\beta$-actin, and horseradish peroxidaseconjugated secondary antibodies from Sigma.

Transfection of siRNA and cell proliferation assay. Transfection of siRNA was performed with Lipofectamine 2000 (from Invitrogen) as described previously (35). In brief, HS578T (0.4-0.6x10 ${ }^{5}$ cells/well) or MDA-MB-231 $\left(1.0 \times 10^{5}\right.$ cells/well $)$ cells in 6-well plates were transfected with 100 pmoles of 
A

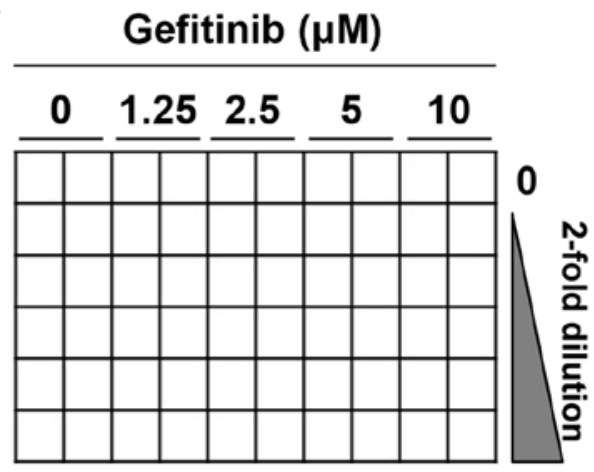

\section{Initial screen with $10 \mu \mathrm{M}$ RTKls}

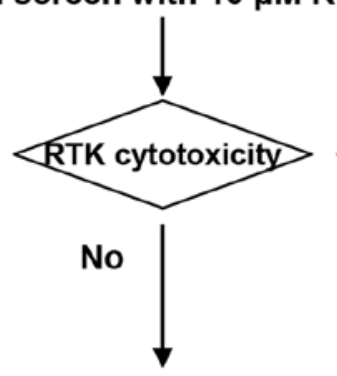

Determine Cls

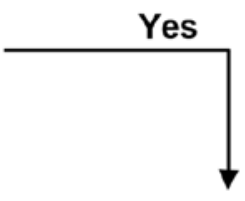

Re-screen

with

educed RTKIs
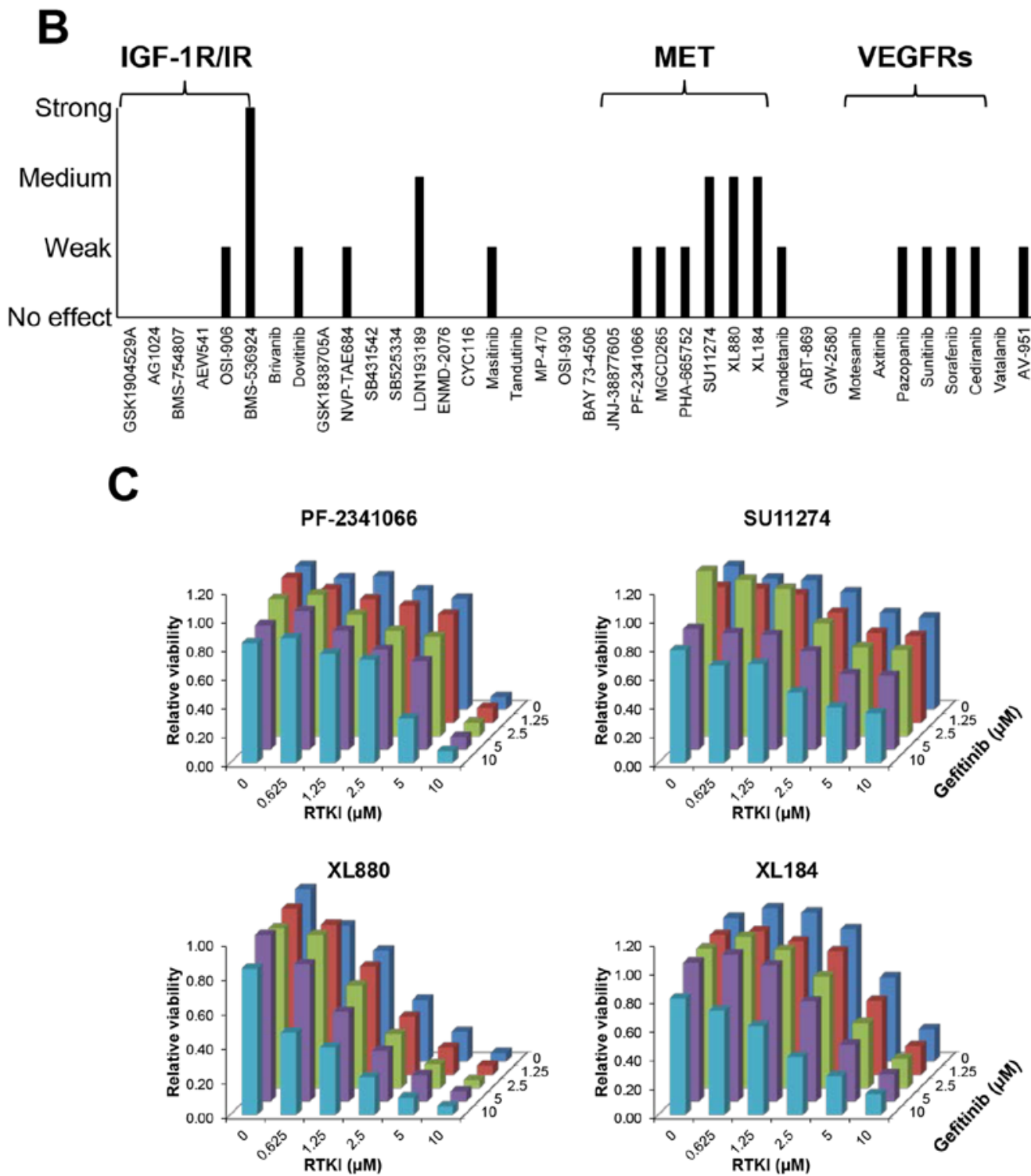

Figure 1. Synthetic lethal screening of MDA-MB-231. (A) Schematic diagram of synthetic lethal screening. (B) RTK inhibitors (RTKIs) which showed synthetic lethality with gefitinib. Strong, medium, and weak synergisms are defined as described in Materials and methods. (C) Representative results of synthetic lethal screening. MDA-MB-231 cells were treated with increasing concentrations of RTKI and gefitinib in duplicates as indicated for $\sim 72 \mathrm{~h}$ and viable cells were determined by MTT assay.

siRNA mixed with $2.5 \mu$ of Lipofectamine 2000 in serum-free DMEM. After 4-h incubation, cells were supplemented with equal volume of DMEM containing $20 \%$ FBS and $200 \mathrm{U} / \mathrm{ml}$ penicillin/streptomycin to maintain normal growth condition and further incubated for 3 days. After 3-day incubation, cells were further supplemented with equal volume of DMEM 
Table I. MET inhibitors identified in this study.

\begin{tabular}{lll}
\hline $\begin{array}{l}\text { Inhibitor } \\
\text { PF-2341066 }\end{array}$ & Other name & \multicolumn{1}{c}{ Known targets $\left(\right.$ IC $_{50}$ in nM) } \\
MGCD265 & Crizotinib & MET (4), ALK (24) \\
PHA-665752 & & MET (1), VEGFR1/2 (3) VEGFR3 (4), RON (2), TIE2 (7) \\
SU11274 & & MET (9) \\
XL880 & MET (10), RON (4000) & MET (0.4), RON (3), VEGFR2 (0.86), FLT1 (6.8), FLT4 (2.8), \\
& Foretinib & KIT (6.7), FLT3 (3.6), PDGFR $(3.6)$, PDGFR 3 (9.6), \\
XL184 & GSK1369089 & TIE2 (1.1), FGFRI1 (660) \\
& Cabozantinib & Met (1.3), VEGFR2 (0.035), KIT (4.6), FLT1 (12), FLT3 (11.3), \\
\hline
\end{tabular}

containing 20\% FBS and $200 \mathrm{U} / \mathrm{ml}$ penicillin/streptomycin and incubated for $\leq 2$ more days. The proliferation of cells was determined by counting viable cells which were stained by acridine orange (AO)/propidium iodide (PI) with the Luna-FL Dual Fluorescence Cell Counter (Logos Biosystems). The siRNAs were purchased from Bioneer (Seoul, Korea) with following sequences: control-siRNA, 5'-GAC GAG CGG CAC GUG CAC AUU-3'; and RPS6-siRNA, 5'-GAA GCA GCG UAC CAA GAA A(dTdT)-3'.

Cell cycle analysis. Cells were treated as indicated and the cells, both attached and floating, were harvested to analyze the cell cycle at the Flow Cytometry and Cell Sorting Shared Resource of Georgetown University Medical Centers described previously (33).

Statistical analysis. The two-tailed Student's t-test was applied for statistical analysis. ${ }^{*} \mathrm{P}<0.05 ;{ }^{* *} \mathrm{P}<0.01 ;{ }^{* * *} \mathrm{P}<0.001$.

\section{Results}

Synthetic lethal screening of RTKIs in MDA-MB-231 cells. Since our previous study identified synergistic effects of EGFR and PI3K/AKT inhibition in a subset of TNBC cells (25), we reasoned that combination of kinase inhibitors with EGFR inhibition might induce synthetic lethality in TNBC cells. We noted that TNBC cells of MSL subtype showed innate resistance to EGFR inhibition. Because overcoming resistance is an unmet need to treat human cancer $(36,37)$, we performed an MTT screening for synthetic lethality with a small library of various RTKIs in MDA-MB-231 cells in the presence of an EGFR inhibitor gefitinib (Fig. 1A). We identified various MET inhibitors (Table I) as potential agents that induced synthetic lethal effects with gefitinib in MDA-MB-231 cells (Fig. 1B). Gefitinib and MET inhibitor combinations synergistically reduced the viable cells in MDA-MB-231 cells in a range of various molar ratios of these drugs (Fig. 1C).

Cytotoxic effect of EGFR and MET inhibitors in human TNBC cell lines. One distinct feature of TNBC is overexpression of EGFR $(6,11,12)$. In addition, a recent study reported that high level expression of MET is an adverse prognostic
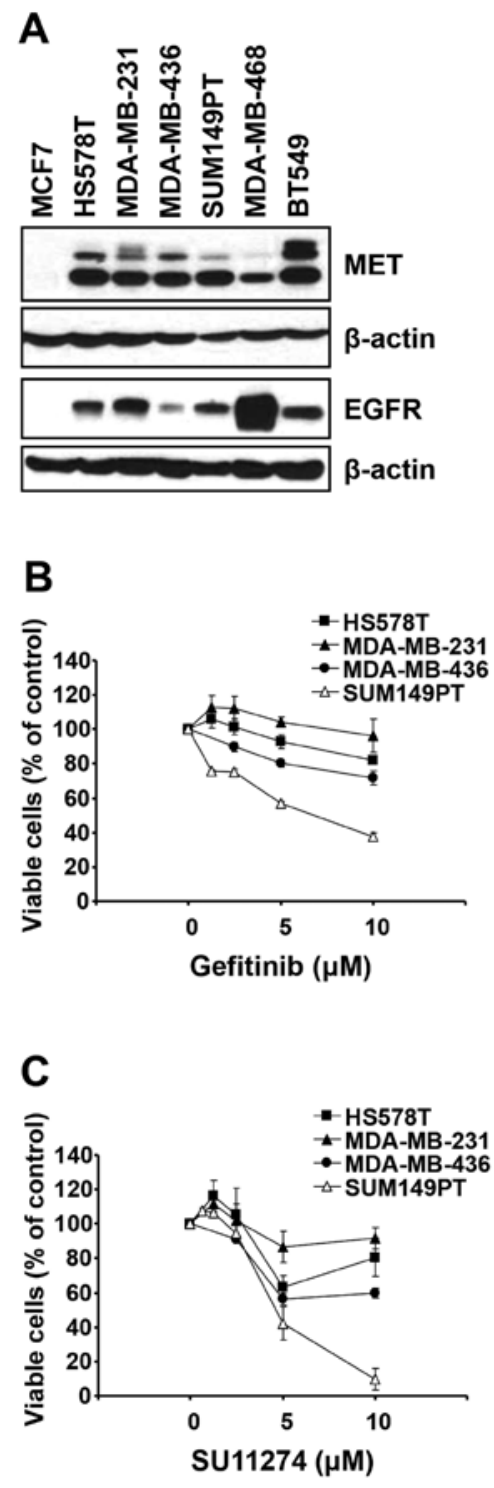

Figure 2. MSL subtype TNBC cells are resistant to either gefitinib or SU11274 in spite of high expression of EGFR and MET. (A) Cell lysates from exponentially growing cells were subjected to western blot analysis with indicated antibodies. $\beta$-actin was used as a loading control. (B and C) Cells were incubated with increasing concentrations of gefitinib (B) or SU11274 (C) for $\leq 72 \mathrm{~h}$ and the viable cells were determined by MTT cell viability assay. Data are presented as mean \pm SEM from three independent experiments performed in triplicate. 
A

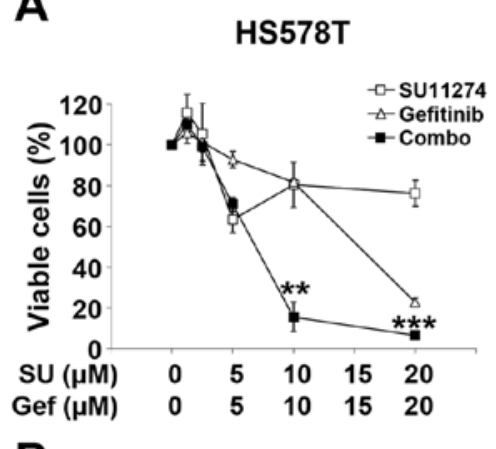

B

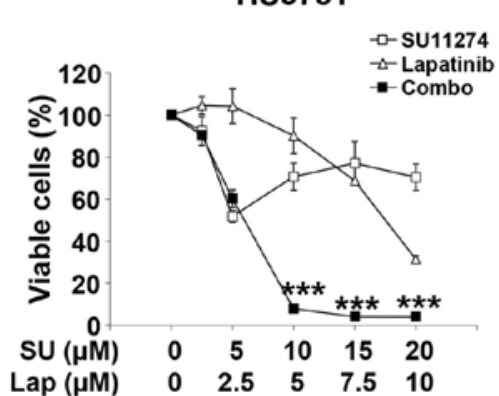

C

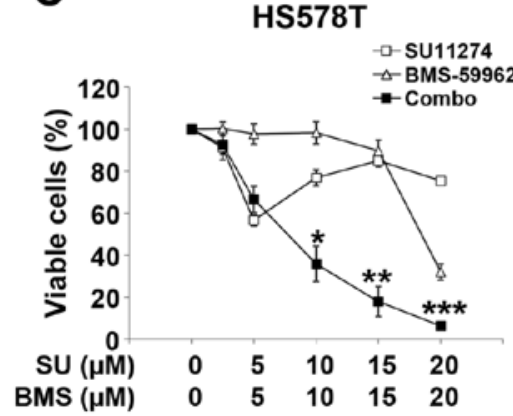

MDA-MB-231

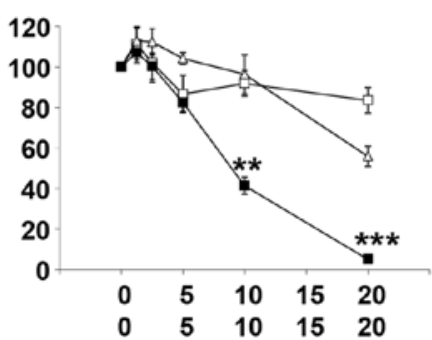

MDA-MB-231

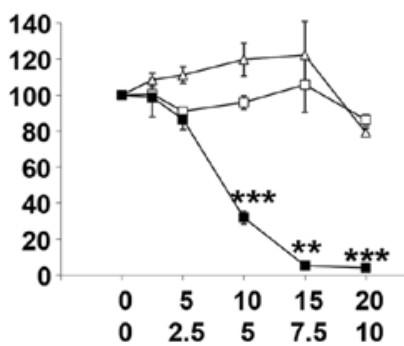

MDA-MB-231

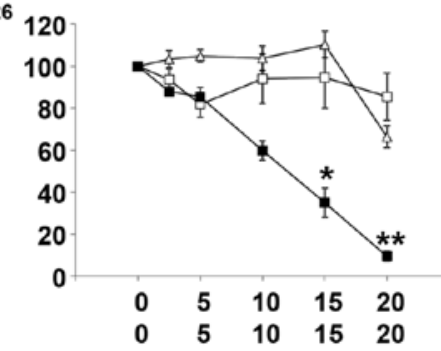

MDA-MB-436

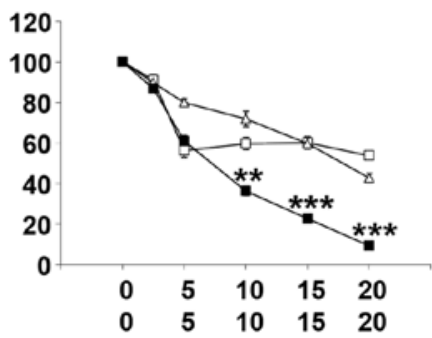

MDA-MB-436

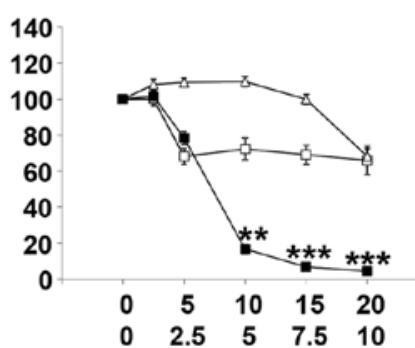

MDA-MB-436

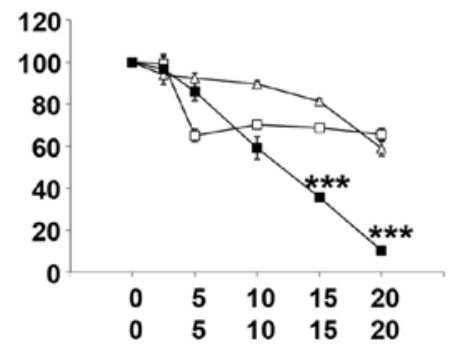

Figure 3. Combination of EGFR inhibitors with SU11274 induces synthetic lethal effect in MSL subtype TNBC cells. Cells were treated with increasing concentrations of compounds as indicated for up to $72 \mathrm{~h}$ and the viable cells were measured by MTT assay. Data are presented as mean \pm SEM from three independent experiments performed in triplicate. SU, SU11274; Gef, gefitinib; Lap, lapatinib; BMS, BMS-599626. ${ }^{*} \mathrm{P}<0.05 ;{ }^{* *} \mathrm{P}<0.01 ;{ }^{* * *} \mathrm{P}<0.001$.

factor in TNBC patients (38). We determined the level of these proteins in a set of TNBC cell lines by western blot analysis. As reported previously (25), the level of EGFR was high in all TNBC cell lines tested compared to the luminal breast cancer cell line MCF7 (Fig. 2A). The level of MET was also higher in TNBC cells than in MCF7 (Fig. 2A).

Since the levels of both EGFR and MET are elevated in human TNBC cell lines, we further determined the cytotoxic effect of EGFR and MET inhibitors as a single agent toward four different human TNBC cell lines. The cells were treated with the EGFR inhibitor gefitinib or the MET inhibitor SU11274 (39) for $\sim 72 \mathrm{~h}$ and the viable cells were determined by MTT cell viability assay. Consistent with a previous report (25), three cell lines (HS578T, MDA-MB-231 and MDA-MB-436) of MSL subtype were relatively resistant to gefitinib compared to a BL2 subtype cell line SUM149PT (Fig. 2B). Gefitinib reduced the viable SUM149PT cells in a dose-dependent manner. On the contrary, the effect of gefitinib was limited on three cell lines of MSL subtype. Additionally, three MSL subtype cell lines were more resistant to SU11274 than SUM149PT cell line (Fig. 2C). Notably, near complete loss of viable cells was observed in SUM149PT cells treated with $10 \mu \mathrm{M}$ of SU11274, while the effect of SU11274 was less potent toward HS578T, MDA-MB-231 and MDA-MB-436 cells.

Synergistic cytotoxic effect of EGFR/MET inhibitor combination in human TNBC cell lines. Since MET inhibitors were identified as potent synthetic lethal agents in combination of gefitinib, we further determined whether the combination of EGFR/MET inhibitors has any beneficial effect in treatment of human TNBC cell lines of MSL subtype. Three types of TNBC cells were treated with increasing concentrations of both EGFR (gefitinib) and MET (SU11274) inhibitors for $\sim 72 \mathrm{~h}$ and the viable cells were determined by MTT assay. Combination of gefitinib and SU11274 with fixed molar ratio of 1:1 markedly reduced the viable cells in HS578T, MDA-MB-231, and MDA-MB-436 cells (Fig. 3A). In addition to gefitinib, lapatinib and BMS-599626 (EGFR/HER2 dual inhibitors) also showed marked synergism with SU11274 (Fig. 3B and C). These results suggest that combination of EGFR/MET inhibitors synergistically reduces the cell viability of MSL subtype cell lines of human TNBC. 
A

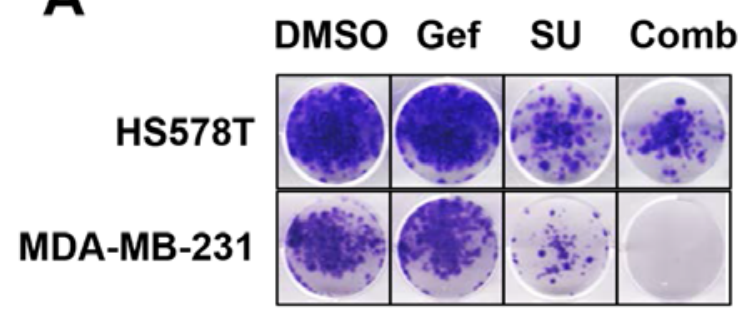

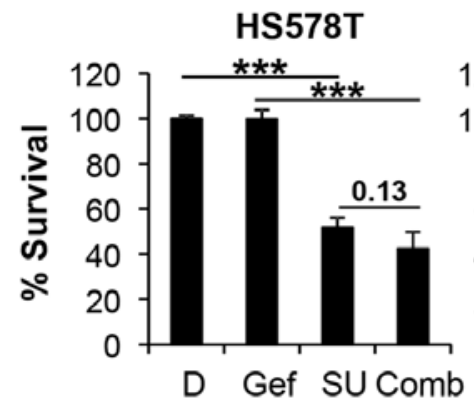

B
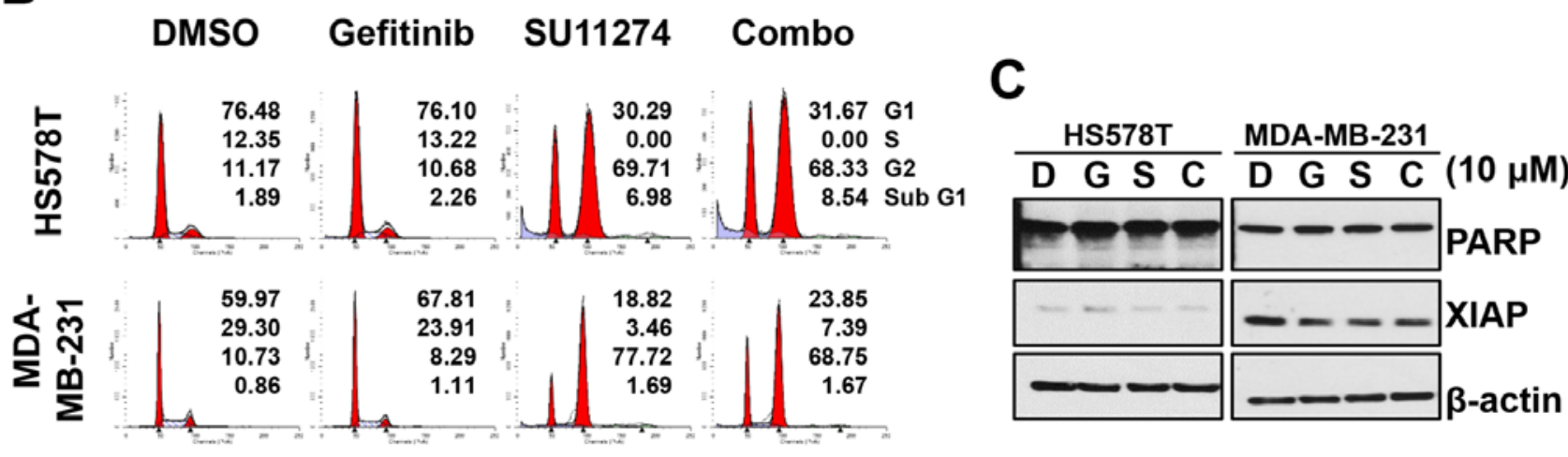

Figure 4. Gefitinib/SU11274 combination reduces survival of TNBC cells through inducing G2 arrest. (A) Cells were treated with compounds (2.5 $\mu$ M for HS578T or $10 \mu \mathrm{M}$ for MDA-MB-231) for $24 \mathrm{~h}$ and further cultivated for 10-14 days in normal growth media. The survived colonies were stained as described in Materials and methods. Left, representative images from two independent experiments performed in triplicate are shown. Right, relative amount of survived colonies were determined as described in Materials and methods. Gef, gefitinib, SU, SU11274; Combo, combination. ${ }^{* * *} \mathrm{P}<0.001$. (B) Cells were treated with $10 \mu \mathrm{M}$ compounds as indicated for $24 \mathrm{~h}$ and the cell cycle distribution was determined by FACS analysis. (C) Cells were treated as indicated for $24 \mathrm{~h}$ and western blot analysis was performed with indicated antibodies. $\beta$-actin was used as a loading control.

Gefitinib/SU11274 combination reduces the survival of human TNBC cell lines. The effect of gefitinib/SU11274 combination was further evaluated by clonogenic cell survival assay. TNBC cells were subcultured in 6-well plates in an appropriate density and treated with drug combinations for $24 \mathrm{~h}$. After wash out of drugs, cells were further cultivated in normal growth media. As shown in Fig. 4A, gefitinib alone could not suppress the number of survived colonies in either HS578T or MDA-MB-231 cells. On the contrary, SU11274, as a single agent, significantly reduced the number of surviving colonies. Consistent with MTT assay, gefitinib/SU11274 combination reduced the colony formation in both cell lines.

The effect of gefitinib/SU11274 combination on the cell cycle distribution was further analyzed. Cells were treated with drugs for $24 \mathrm{~h}$ and the cells, both attached and floating, were collected to determine the cell cycle. As shown in Fig. 4B, gefitinib alone could not significantly affect the cell cycle distribution of HS578T and MDA-MB-231 cells. However, treatment of SU11274 markedly induced the accumulation of G2 accompanying by reduction of both G1 and S phase in both cell lines. The cell cycle distribution induced by SU11274 was sustained in the cells which were treated with gefitinib/ SU11274 combination.

To detect apoptotic cell death, we further analyzed the Poly (ADP-ribose) polymerase (PARP) cleavage and the level of $\mathrm{X}$-linked inhibitor of apoptosis protein (XIAP) by western blot analysis. HS578T and MDA-MB-231 cells were treated with compounds for $24 \mathrm{~h}$ and the lysates were subjected to western blot analysis. As shown in Fig. 4C, no apparent induction of
PARP cleavage was observed. The level of XIAP protein was also marginally reduced by gefitinib/SU11274 combination.

Combination of gefitinib/SU11274 synergistically reduces the level of RPS6 in MSL subtype TNBC cells. To determine signaling pathways mediating the gefitinib/SU11274 effect, we performed a series of western blot analyses. HS578T and MDA-MB-231 cells were treated with increasing concentrations of drugs for $24 \mathrm{~h}$, either single agents or combination, then the lysates from these cells were subjected to western blot analysis. Interestingly, single agent treatment, either gefitinib or SU11274 for $24 \mathrm{~h}$, reduced the level of phospho-ribosomal protein S6 (RPS6) (S235/S236) in HS578T and MDA-MB-231 cells in a dose-dependent manner (Fig. 5A). In addition, gefitinib/SU11274 combination synergistically reduced the level of phospho-RPS6 in these cells. Surprisingly, the level of RPS6 protein itself was reduced by these drugs as single agents and further reduced by combination treatment.

Unexpectedly, 24-h treatment of gefitinib did not reduce the level of phospho-EGFR (Y1068) in these cells, while gefitinib/ SU11274 combination reduced the level of phospho-EGFR (Y1068) only in MDA-MB-231 cells (Fig. 5B). As expected, SU11274 reduced the level of phospho-MET (Y1234/Y1235) in these cells (Fig. 5B). In addition, the level of phospho-MET was also reduced by gefitinib in both cell types. However, neither gefitinib nor SU11274 could reduce the levels of phospho-AKT (S473) and phospho-ERK1/2 (T202/Y204). The gefitinib/SU11274 combination could not reduce either phospho-AKT or phospho-ERK1/2 (Fig. 5B). These results 
A

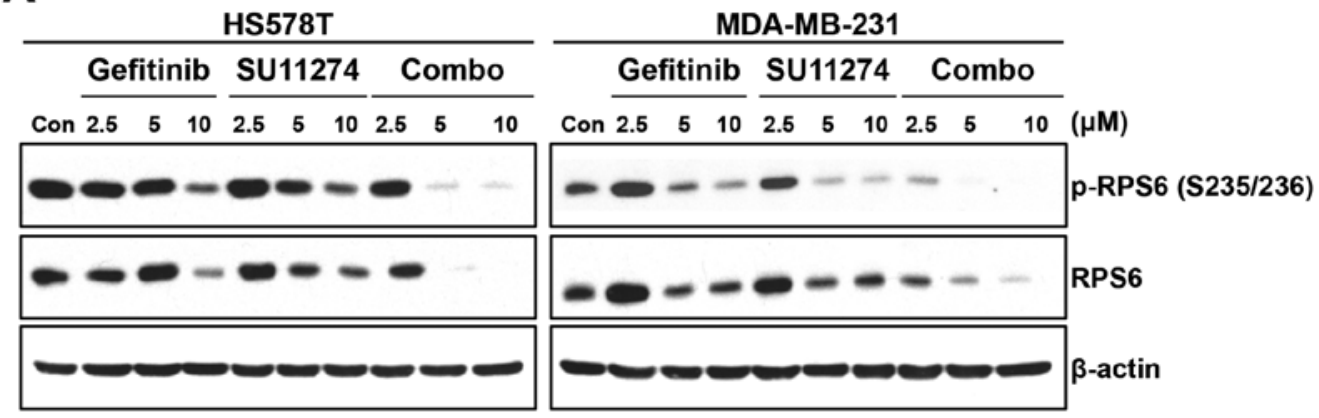

B

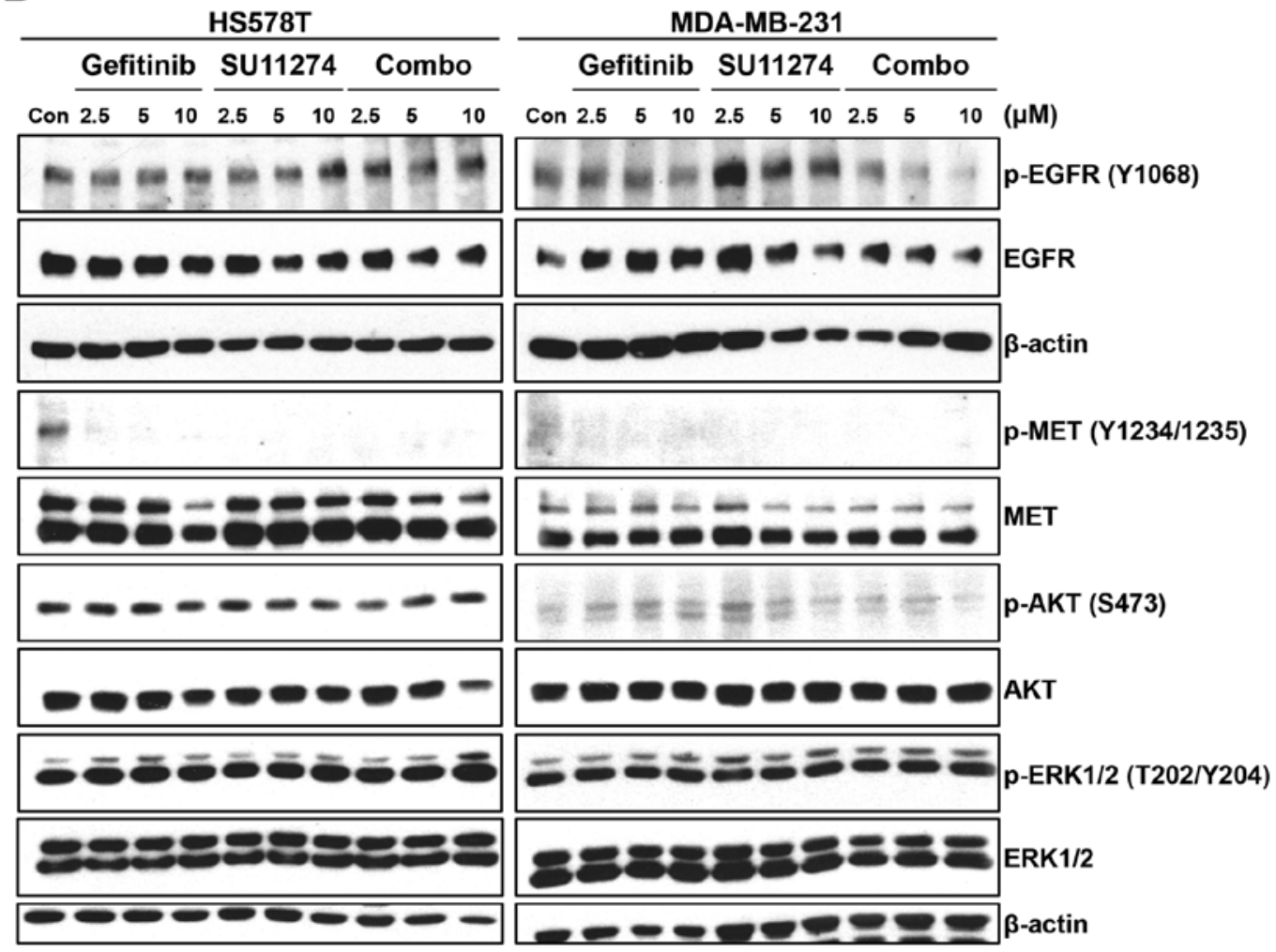

Figure 5. Gefitinib/SU11274 combination reduces the level of phospho-RPS6 (S235/236) and RPS6 in TNBC cells. (A and B) Cells were treated with increasing amounts of compounds as indicated for $24 \mathrm{~h}$ and western blot analysis was performed with indicated antibodies. $\beta$-actin was used as a loading control.

suggest that 24-h treatment of gefitinib or SU11274 could not inhibit the AKT and ERK pathways in these cell lines.

Gefitinib/SU11274 combination reduces the level of RPS6 in a proteasome-independent manner. To determine the level of RPS6 over time, cells were treated with gefitinib/SU11274 combination for several time intervals and the level of RPS6 proteins was detected by western blot analysis (Fig. 6A). Interestingly, the decrease of both phospho-RPS6 (S235/236) and RPS6 itself was evident as early as $1 \mathrm{~h}$ after treatment (Fig. 6A). In addtion, the decrease of RPS6 protein level was sustained for up to $16 \mathrm{~h}$. The level of phospho-AKT (S473) was decreased at $1 \mathrm{~h}$ after combination treatment. However, the decrease of phospho-AKT (S473) was reversed over time in both cell lines (Fig. 6A).

The effect of proteasome inhibition on the level of RPS6 was also determined by western blot analysis (Fig. 6B). Cells were treated with $10 \mu \mathrm{M}$ of either gefitinib or SU11274 and combination of both drugs for $4 \mathrm{~h}$ in the presence of the proteasome inhibitor MG132. Consistently, gefitinib/SU11274 combination markedly reduced the level of RPS6 in both cell lines. However, the treatment of MG132 did not affect gefitinib/SU11274-mediated reduction of RPS6 (Fig. 6B). Contrary to $24-\mathrm{h}$ treatment, $4-\mathrm{h}$ treatment of $10 \mu \mathrm{M}$ gefitinib reduced the level of phospho-EGFR (Y1068) in these cells. In addition, gefitinib/SU11274 combination further reduced the level of phospho-EGFR. These results suggest that gefitinib/ SU11274 combination induces irreversible reduction of RPS6 in a proteasome-independent manner.

Knockdown of RPS6 reduces the proliferation of TNBC cells. Since gefitinib/SU11274 combination synergistically reduced the level of RPS6 in MSL subtype TNBC cells, we questioned whether RPS6 is important to the proliferation of these cells. To address this, we knocked down the RPS6 protein by specific siRNA. HS578T cells and MDA-MB-231 cells were 
A

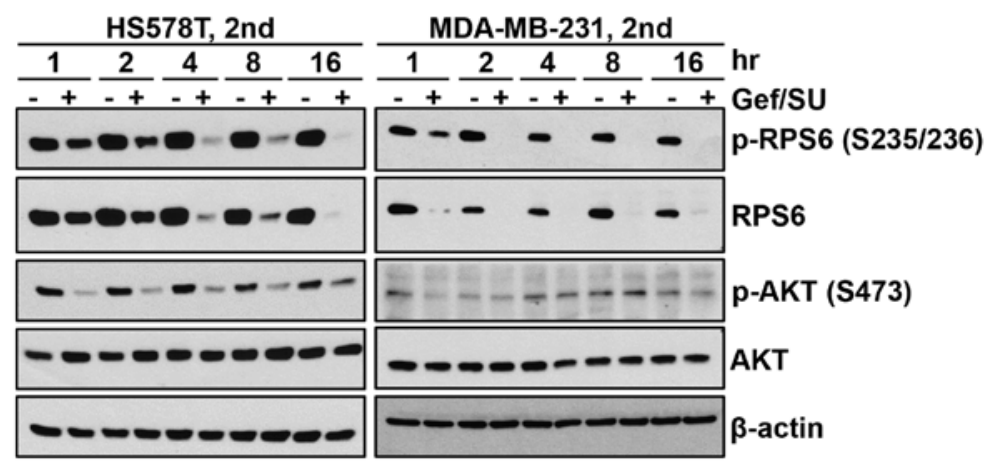

B

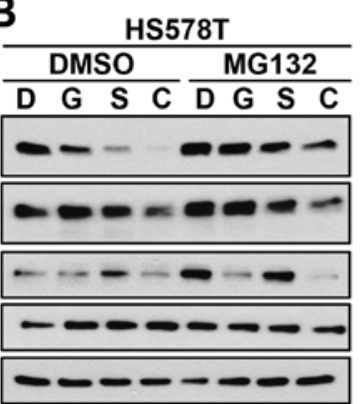

MDA-MB-231

\begin{tabular}{|c|c|}
\hline DMSO MG132 & \\
\hline$D \quad G \quad S \quad C \quad D G S C$ & $(10 \mu \mathrm{M})$ \\
\hline 0650000 & p-RPS6 (S235/236 \\
\hline 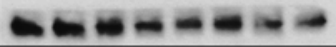 & PRS6 \\
\hline$-\cdots-\infty-0$ & p-EGFR (Y1068) \\
\hline$-\infty-\infty-\infty-$ & EGFR \\
\hline$-\infty-1-\infty-\infty$ & $\beta$-actin \\
\hline
\end{tabular}

Figure 6. The level of RPS6 is reduced by gefitinib/SU11274 combination in a proteasome-independent manner. (A) HS578T and MDA-MB-231 cells were treated with either DMSO or gefitinib/SU11274 combination (10 $\mu \mathrm{M}$, respectively) for indicated time and western blot analysis was performed with indicated antibodies. $\beta$-actin was used as a loading control. (B) HS578T and MDA-MB-231 cells were treated with compounds as indicated in the absence or presence of $10 \mu \mathrm{M}$ of MG132 for $4 \mathrm{~h}$ and western blot analysis was performed with indicated antibodies. $\beta$-actin was used as a loading control.

A

HS578T

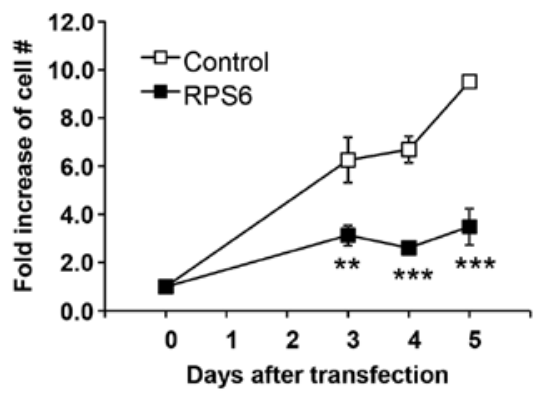

B

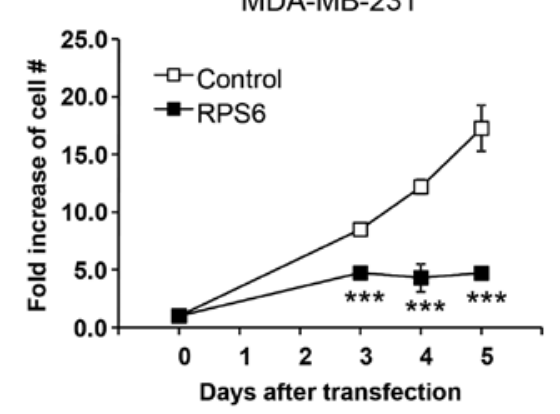

MDA-MB-231

MDA-MB-231
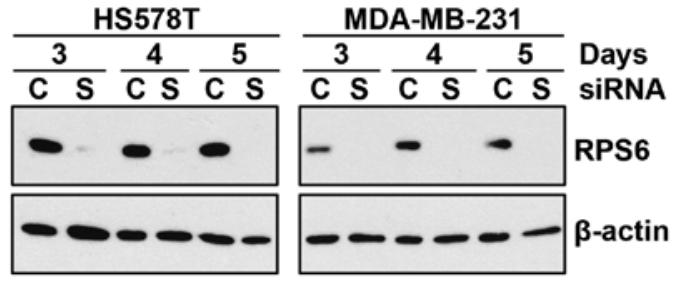

Figure 7. Knockdown of RPS6 reduces the proliferation of TNBC cells. (A) HS578T and MDA-MB-231 cells were transfected with either control- and RPS6-siRNA as described in Materials and methods and the number of viable cells was determined by counting viable cells with AO/PI staining. Representative data are presented as mean \pm SEM from two independent experiments performed in triplicate. ${ }^{* *} \mathrm{P}<0.01 ;{ }^{* * * *} \mathrm{P}<0.001$. (B) Cells were transfected with siRNAs as described (A) and western blot analysis was performed with indicated antibodies. $\beta$-actin was used as a loading control.

transfected with either control- or RPS6-siRNA and cultivated for up to 5 days. The difference of cell proliferation was traced by viable cell counting at indicated days. As shown in Fig. 7A, knockdown of RPS6 profoundly reduced the proliferation of both HS578T and MDA-MB-231 cells as early as 3 days after siRNA transfection. Western blot analysis confirmed the 
knockdown of RPS6 under these conditions (Fig. 7B). Taken together, our data suggest that gefitinib/SU11274 combination reduced the proliferation of a subset of TNBC cells through downregulation of RPS6 proteins.

\section{Discussion}

In the present study, we demonstrated that the MET inhibitor SU11274 is a synthetic lethal agent in the combination with EGFR inhibitors for the MSL subtype of TNBC cells. The levels of EGFR and MET are highly elevated in TNBC cells tested. Nevertheless, EGFR inhibitors (gefitinib, lapatinib, and BMS-599626) and SU11274 has limited potency in TNBC cells of MSL subtype such as HS578T, MDA-MB-231, and MDA-MB436 in MTT assay. However, the combination of these drugs markedly reduced the viable cells in MTT assays and survival of these cells in clonogenic assays. One notable feature of these combinations is the reduction of RPS6 protein levels. Treatment of gefitinib/SU11274 combination for $24 \mathrm{~h}$ did not affect various signaling pathways including AKT and ERK. However, the level of phospho-RPS6 (S235/236) was synergistically reduced by this combination. The reduction of phospho-RPS6 (S235/236) was due to the reduction of RPS6 protein itself as early as $1 \mathrm{~h}$ after combination treatment. Although the level of phosphoAKT (S473) was reduced by this combination in early time points, it was reversed over time and near completely recovered at $16 \mathrm{~h}$ after treatment. On the contrary, the initial reduction of RPS6 protein level was maintained over time. Proteasome inhibition did not reverse the reduction of RPS6 by gefitinib/ SU11274 combination. Interestingly, siRNA-based knockdown of RPS6 itself was enough to reduce the proliferation of HS578T and MDA-MB-231 cells. Taken together our data suggest that dual inhibition of EGFR and MET induces synthetic lethality in a subtype of TNBC cells through downregulation of RPS6 protein.

MET, a member of receptor tyrosine kinase, is activated by hepatocyte growth factor/scatter factor (HGF/SF) (40). The binding of HGF to MET activates various signal pathways including RAS/MAPK, PI3K/AKT, SRC and STAT3/5 and these signal pathways mediate normal cell proliferation, cell scattering, invasion, migration, embryogenesis, evading apoptosis, angiogenesis, and tissue regeneration (41). MET and HGF are highly expressed in a wide variety of cancers including lung, ovary, renal, gastric, pancreas, head and neck and colon cancers and are also considered to contribute to unregulated cell proliferation, reduced apoptosis, altered cytoskeletal function, tumor cell scattering, migration, dissemination, and invasion during cancer cell metastasis (41-43). However, the roles of MET in the proliferation and/or survival of TNBC cells is largely unappreciated. A recent study demonstrated that paracrine activation of MET by fibroblast-secreted HGF induces gefitinib resistance in two TNBC cell lines, SUM102 and SUM149PT (44). It has also been reported that MET is colocalized with AXL receptor kinase complex which includes EGFR, HER2/3, MET and platelet-derived growth factor receptor $\beta$ (PDGFR $\beta$ ) in TNBC cells (45). Inhibition of MET was also reported as a potential opportunity of Notch targeting for TNBC patients with MET overexpression and Notch hyperactivation (46). More recently, the MET inhibitor PHA-665752 with the EGFR inhibitor erlotinib was demonstrated to reduce the viability of the BL1 subtype TNBC MDA-MB-468 cells (47). In the present study, we found that $10 \mu \mathrm{M}$ treatment of the MET inhibitor SU11274 exhibited a limited potency toward MSL subtype TNBC cells in MTT assay, while 24-h treatment of $10 \mu \mathrm{M}$ SU11274 showed significant reduction of TNBC cell survival in clonogenic assay. Interestingly, SU11274 alone induced significant increase of cells in G2 phase of cell cycle. These results suggest that MET itself might have potential role in the regulation of the cell cycle and/or long-term survival of MSL subtype TNBC cells. Further study will be needed to decipher the role of MET in the proliferation and/or survival of TNBC cells.

Our present data suggest that co-targeting EGFR and MET trigger an irreversible reduction of RPS6 protein: while the inhibition of upstream signaling pathway such as EGFR and AKT was reversed with time, the initial reduction of RPS6 protein level was sustained. In addition, knockdown of RPS6 itself significantly reduced the proliferation of MSL subtype TNBC cells in the present study. These results suggest that reduction of RPS6 by gefitinib/SU11274 combination is sufficient to inhibit the proliferation of MSL subtype TNBC cells. RPS6 protein is evolutionarily conserved from yeast to vertebrate and indispensable for protein synthesis (48). Despite the fact that increased phosphorylation and mRNA upregulation of RPS6 has been reported in several human cancers (49-61), the role of RPS6 in cancer initiation and/or progression has not been well appreciated. Recently, the potential implication of RPS6 in human cancer was revealed by knockdown experiments. Knockdown of RPS6 by siRNA reduced the survival of Ewing family tumor cell lines with near complete cell death in a siRNA library screening (62). Knockdown of RPS6 by shRNA was also reported to reduce the proliferation of diffuse large B-cell lymphoma (DLBCL) cell lines (57). Phospho-RPS6 has been reported to attenuate KRAS-induced DNA damage in acinar cells and in acinar-to-ductal metaplasia (ADM) and p53-mediated tumor suppression during initiation of pancreatic cancer (63). Collectively, targeting RPS6 may provide alternative therapeutic regimen to treat human cancers with high level of RPS6.

RPS6 protein is phosphorylated at multiple sites by various upstream kinases such as RPS6 kinase $\alpha 1$ (RPS6KA1), RPS6KA3, death-associated protein kinase 1 (DAPK1), and PAS domain containing serine/threonine kinase (PASK) (64-69). The phosphorylation of RPS6 is involved in the regulation of global protein synthesis that determines the size of cells, cell proliferation, and glucose homeostasis (48). RPS6 is also known to be important to cap-dependent protein translation (67). Unfortunately, the regulation of RPS6 protein stability has not yet been explored. Heat shock protein 90 (HSP90), a molecular chaperone, binds to RPS6 (70) and regulates its degradation through ubiquitin-dependent proteolysis (71). In addition, the HSP90 inhibitor geldanamycin reduces the level of RPS6 (71).

In the present study, the reduction of RPS6 by gefitinib/ SU11274 combination was not reversed by the proteasome inhibitor MG132. Since the reduction of RPS6 itself was as rapid as $1 \mathrm{~h}$ after treatment, it is plausible that active proteolysis regulates the gefitinib/SU11274-mediated reduction of RPS6 level. Further study is needed to address how RPS6 stability is regulated by this combination in TNBC cells. 


\section{Acknowledgements}

This study was supported by the Susan G. Komen for the Cure (FAS0703858) and by the Lombardi Comprehensive Cancer Center, Georgetown University Medical Center (P30-CA051008) awarded to the late Professor Insoo Bae.

\section{References}

1. Siegel R, Ma J, Zou Z and Jemal A: Cancer statistics, 2014. CA Cancer J Clin 64: 9-29, 2014

2. Lehmann BD, Bauer JA, Chen X, Sanders ME, Chakravarthy AB, Shyr Y and Pietenpol JA: Identification of human triple-negative breast cancer subtypes and preclinical models for selection of targeted therapies. J Clin Invest 121: 2750-2767, 2011.

3. Morris GJ, Naidu S, Topham AK, Guiles F, Xu Y, McCue P, Schwartz GF, Park PK, Rosenberg AL, Brill K, et al: Differences in breast carcinoma characteristics in newly diagnosed AfricanAmerican and Caucasian patients: A single-institution compilation compared with the National Cancer Institute's Surveillance, Epidemiology, and End Results database. Cancer 110: 876-884, 2007.

4. Irvin WJ Jr and Carey LA: What is triple-negative breast cancer? Eur J Cancer 44: 2799-2805, 2008.

5. Liedtke C, Mazouni C, Hess KR, André F, Tordai A, Mejia JA, Symmans WF, Gonzalez-Angulo AM, Hennessy B, Green M, et al: Response to neoadjuvant therapy and long-term survival in patients with triple-negative breast cancer. J Clin Oncol 26 : 1275-1281, 2008.

6. Podo F, Buydens LM, Degani H, Hilhorst R, Klipp E, Gribbestad IS, Van Huffel S, van Laarhoven HW, Luts J, Monleon D, et al: FEMME Consortium: Triple-negative breast cancer: Present challenges and new perspectives. Mol Oncol 4: 209-229, 2010.

7. Eccles SA: The epidermal growth factor receptor/Erb-B/HER family in normal and malignant breast biology. Int J Dev Biol 55: 685-696, 2011.

8. Yarden Y and Pines G: The ERBB network: At last, cancer therapy meets systems biology. Nat Rev Cancer 12: 553-563, 2012.

9. Reis-Filho JS, Milanezi F, Carvalho S, Simpson PT, Steele D, Savage K, Lambros MB, Pereira EM, Nesland JM, Lakhani SR, et al: Metaplastic breast carcinomas exhibit EGFR, but not HER2, gene amplification and overexpression: Immunohistochemical and chromogenic in situ hybridization analysis. Breast Cancer Res 7: R1028-R1035, 2005

10. Reis-Filho JS, Pinheiro C, Lambros MB, Milanezi F, Carvalho S, Savage K, Simpson PT, Jones C, Swift S, Mackay A, et al: EGFR amplification and lack of activating mutations in metaplastic breast carcinomas. J Pathol 209: 445-453, 2006.

11. Livasy CA, Karaca G, Nanda R, Tretiakova MS, Olopade OI, Moore DT and Perou CM: Phenotypic evaluation of the basal-like subtype of invasive breast carcinoma. Mod Pathol 19: 264-271, 2006

12. Nielsen TO, Hsu FD, Jensen K, Cheang M, Karaca G, Hu Z, Hernandez-Boussard T, Livasy C, Cowan D, Dressler L, et al: Immunohistochemical and clinical characterization of the basallike subtype of invasive breast carcinoma. Clin Cancer Res 10 5367-5374, 2004

13. Lehmann BD and Pietenpol JA: Identification and use of biomarkers in treatment strategies for triple-negative breast cancer subtypes. J Pathol 232: 142-150, 2014.

14. Dawson SJ, Provenzano E and Caldas C: Triple negative breast cancers: Clinical and prognostic implications. Eur J Cancer 45 (Suppl 1): 27-40, 2009.

15. Lakhani SR, Reis-Filho JS, Fulford L, Penault-Llorca F, van der Vijver M, Parry S, Bishop T, Benitez J, Rivas C, Bignon YJ, et al: Prediction of BRCA1 status in patients with breast cancer using estrogen receptor and basal phenotype. Clin Cancer Res 11: 5175-5180, 2005 .

16. Cheang MC, Voduc D, Bajdik C, Leung S, McKinney S, Chia SK, Perou CM and Nielsen TO: Basal-like breast cancer defined by five biomarkers has superior prognostic value than triple-negative phenotype. Clin Cancer Res 14: 1368-1376, 2008.

17. Rakha EA, El-Sayed ME, Green AR, Lee AH, Robertson JF and Ellis IO: Prognostic markers in triple-negative breast cancer. Cancer 109: 25-32, 2007

18. Tischkowitz M, Brunet JS, Bégin LR, Huntsman DG, Cheang MC, Akslen LA, Nielsen TO and Foulkes WD: Use of immunohistochemical markers can refine prognosis in triple negative breast cancer. BMC Cancer 7: 134, 2007.
19. Baselga J, Gómez P, Greil R, Braga S, Climent MA, Wardley AM, Kaufman B, Stemmer SM, Pêgo A, Chan A, et al: Randomized phase II study of the anti-epidermal growth factor receptor monoclonal antibody cetuximab with cisplatin versus cisplatin alone in patients with metastatic triple-negative breast cancer. J Clin Oncol 31: 2586-2592, 2013.

20. Bernsdorf M, Ingvar C, Jörgensen L, Tuxen MK, Jakobsen EH, Saetersdal A, Kimper-Karl ML, Kroman N, Balslev E and Ejlertsen B: Effect of adding gefitinib to neoadjuvant chemotherapy in estrogen receptor negative early breast cancer in a randomized phase II trial. Breast Cancer Res Treat 126: 463-470, 2011.

21. Carey LA, Rugo HS, Marcom PK, Mayer EL, Esteva FJ, Ma CX, Liu MC, Storniolo AM, Rimawi MF, Forero-Torres A, et al: TBCRC 001: Randomized phase II study of cetuximab in combination with carboplatin in stage IV triple-negative breast cancer. J Clin Oncol 30: 2615-2623, 2012.

22. Anderson NG, Ahmad T, Chan K, Dobson R and Bundred NJ: ZD1839 (Iressa), a novel epidermal growth factor receptor (EGFR) tyrosine kinase inhibitor, potently inhibits the growth of EGFR-positive cancer cell lines with or without erbB2 overexpression. Int J Cancer 94: 774-782, 2001.

23. Ciardiello F, Caputo R, Bianco R, Damiano V, Pomatico G, De Placido S, Bianco AR and Tortora G: Antitumor effect and potentiation of cytotoxic drugs activity in human cancer cells by ZD-1839 (Iressa), an epidermal growth factor receptor-selective tyrosine kinase inhibitor. Clin Cancer Res 6: 2053-2063, 2000.

24. Wakeling AE, Guy SP, Woodburn JR, Ashton SE, Curry BJ, Barker AJ and Gibson KH: ZD1839 (Iressa): An orally active inhibitor of epidermal growth factor signaling with potential for cancer therapy. Cancer Res 62: 5749-5754, 2002.

25. Yi YW, Hong W, Kang HJ, Kim HJ, Zhao W, Wang A, Seong YS and Bae I: Inhibition of the PI3K/AKT pathway potentiates cytotoxicity of EGFR kinase inhibitors in triple-negative breast cancer cells. J Cell Mol Med 17: 648-656, 2013.

26. Jin Q and Esteva FJ: Cross-talk between the ErbB/HER family and the type I insulin-like growth factor receptor signaling pathway in breast cancer. J Mammary Gland Biol Neoplasia 13: 485-498, 2008

27. Karamouzis MV, Konstantinopoulos PA and Papavassiliou AG: Targeting MET as a strategy to overcome crosstalk-related resistance to EGFR inhibitors. Lancet Oncol 10: 709-717, 2009.

28. Liu P, Cheng H, Roberts TM and Zhao JJ: Targeting the phosphoinositide 3-kinase pathway in cancer. Nat Rev Drug Discov 8: 627-644, 2009.

29. Nahta R, Yu D, Hung MC, Hortobagyi GN and Esteva FJ: Mechanisms of disease: Understanding resistance to HER2targeted therapy in human breast cancer. Nat Clin Pract Oncol 3: 269-280, 2006

30. Yamaguchi H, Chang SS, Hsu JL and Hung MC: Signaling crosstalk in the resistance to HER family receptor targeted therapy. Oncogene 33: 1073-1081, 2014.

31. Baselga J: Targeting tyrosine kinases in cancer: The second wave. Science 312: 1175-1178, 2006.

32. Morgillo F, Kim WY, Kim ES, Ciardiello F, Hong WK and Lee HY: Implication of the insulin-like growth factor-IR pathway in the resistance of non-small cell lung cancer cells to treatment with gefitinib. Clin Cancer Res 13: 2795-2803, 2007.

33. Yi YW, Kang HJ, Kim HJ, Kong Y, Brown ML and Bae I: Targeting mutant p53 by a SIRT1 activator YK-3-237 inhibits the proliferation of triple-negative breast cancer cells. Oncotarget 4: 984-994, 2013.

34. Duong HQ, Yi YW, Kang HJ, Hong YB, Tang W, Wang A, Seong YS and Bae I: Inhibition of NRF2 by PIK-75 augments sensitivity of pancreatic cancer cells to gemcitabine. Int J Oncol 44: 959-969, 2014.

35. Hou S, Yi YW, Kang HJ, Zhang L, Kim HJ, Kong Y, Liu Y, Wang K, Kong HS, Grindrod S, et al: Novel carbazole inhibits phospho-STAT3 through induction of protein-tyrosine phosphatase PTPN6. J Med Chem 57: 6342-6353, 2014.

36. Lovly CM and Shaw AT: Molecular pathways: resistance to kinase inhibitors and implications for therapeutic strategies. Clin Cancer Res 20: 2249-2256, 2014.

37. Szakács G, Paterson JK, Ludwig JA, Booth-Genthe C and Gottesman MM: Targeting multidrug resistance in cancer. Nat Rev Drug Discov 5: 219-234, 2006.

38. Zagouri F, Bago-Horvath Z, Rössler F, Brandstetter A, Bartsch R, Papadimitriou CA, Dimitrakakis C, Tsigginou A, Papaspyrou I, Giannos A, et al: High MET expression is an adverse prognostic factor in patients with triple-negative breast cancer. Br J Cancer 108: 1100-1105, 2013 
39. Wang X, Le P, Liang C, Chan J, Kiewlich D, Miller T, Harris D, Sun L, Rice A, Vasile S, et al: Potent and selective inhibitors of the Met [hepatocyte growth factor/scatter factor (HGF/SF) receptor] tyrosine kinase block $\mathrm{HGF} / \mathrm{SF}$-induced tumor cell growth and invasion. Mol Cancer Ther 2: 1085-1092, 2003.

40. Ma PC, Maulik G, Christensen J and Salgia R: c-Met: Structure, functions and potential for therapeutic inhibition. Cancer Metastasis Rev 22: 309-325, 2003.

41. Christensen JG, Schreck R, Burrows J, Kuruganti P, Chan E, Le P, Chen J, Wang X, Ruslim L, Blake R, et al: A selective small molecule inhibitor of c-Met kinase inhibits c-Met-dependent phenotypes in vitro and exhibits cytoreductive antitumor activity in vivo. Cancer Res 63: 7345-7355, 2003.

42. Sierra JR and Tsao MS: c-MET as a potential therapeutic target and biomarker in cancer. Ther Adv Med Oncol 3 (Suppl): S21-S35, 2011.

43. Trusolino L and Comoglio PM: Scatter-factor and semaphorin receptors: Cell signalling for invasive growth. Nat Rev Cancer 2 : 289-300, 2002

44. Mueller KL, Madden JM, Zoratti GL, Kuperwasser C, List K and Boerner JL: Fibroblast-secreted hepatocyte growth factor mediates epidermal growth factor receptor tyrosine kinase inhibitor resistance in triple-negative breast cancers through paracrine activation of Met. Breast Cancer Res 14: R104, 2012.

45. Meyer AS, Miller MA, Gertler FB and Lauffenburger DA: The receptor AXL diversifies EGFR signaling and limits the response to EGFR-targeted inhibitors in triple-negative breas cancer cells. Sci Signal 6: ra66, 2013.

46. Zhang S, Chung WC, Miele L and Xu K: Targeting Met and Notch in the Lfng-deficient, Met-amplified triple-negative breast cancer. Cancer Biol Ther 15: 633-642, 2014.

47. Kim YJ, Choi JS, Seo J, Song JY, Lee SE, Kwon MJ, Kwon MJ, Kundu J, Jung K, Oh E, et al: MET is a potential target for use in combination therapy with EGFR inhibition in triple-negative/ basal-like breast cancer. Int J Cancer 134: 2424-2436, 2014.

48. Meyuhas O: Physiological roles of ribosomal protein S6: One of its kind. Int Rev Cell Mol Biol 268: 1-37, 2008.

49. Barrows BD, Rutkowski MJ, Gültekın SH, Parsa AT and Tıhan T: Evidence of ambiguous differentiation and mTOR pathway dysregulation in subependymal giant cell astrocytoma. Turk Patoloji Derg 28: 95-103, 2012.

50. Bellizzi AM, Bloomston M, Zhou XP, Iwenofu $\mathrm{OH}$ and Frankel WL: The mTOR pathway is frequently activated in pancreatic ductal adenocarcinoma and chronic pancreatitis. Appl Immunohistochem Mol Morphol 18: 442-447, 2010.

51. Chaisuparat R, Rojanawatsirivej S and Yodsanga S: Ribosomal protein S6 phosphorylation is associated with epithelial dysplasia and squamous cell carcinoma of the oral cavity. Pathol Oncol Res 19: 189-193, 2013

52. Chaisuparat R, Yodsanga S, Montaner S and Jham BC: Activation of the Akt/mTOR pathway in dentigerous cysts, odontogenic keratocysts, and ameloblastomas. Oral Surg Oral Med Oral Pathol Oral Radiol 116: 336-342, 2013.

53. Chakraborty S, Mohiyuddin SM, Gopinath KS and Kumar A Involvement of TSC genes and differential expression of other members of the mTOR signaling pathway in oral squamous cell carcinoma. BMC Cancer 8: 163, 2008.

54. Chen W, Drakos E, Grammatikakis I, Schlette EJ, Li J, Leventaki V, Staikou-Drakopoulou E, Patsouris E, Panayiotidis P, Medeiros LJ, et al: mTOR signaling is activated by FLT3 kinase and promotes survival of FLT3-mutated acute myeloid leukemia cells. Mol Cancer 9: 292, 2010.

55. Chiang DY, Villanueva A, Hoshida Y, Peix J, Newell P, Minguez B, LeBlanc AC, Donovan DJ, Thung SN, Solé M, et al: Focal gains of VEGFA and molecular classification of hepatocellular carcinoma. Cancer Res 68: 6779-6788, 2008

56. Golfinopoulos V, Pentheroudakis G, Goussia A, Siozopoulou V, Bobos M, Krikelis D, Cervantes A, Ciuleanu T, Marselos M, Fountzilas G, et al: Intracellular signalling via the AKT axis and downstream effectors is active and prognostically significant in cancer of unknown primary (CUP): a study of 100 CUP cases. Ann Oncol 23: 2725-2730, 2012.

57. Hagner PR, Mazan-Mamczarz K, Dai B, Balzer EM, Corl S, Martin SS, Zhao XF and Gartenhaus RB: Ribosomal protein S6 is highly expressed in non-Hodgkin lymphoma and associates with mRNA containing a 5 ' terminal oligopyrimidine tract. Oncogene 30: 1531-1541, 2011

58. Iwenofu OH, Lackman RD, Staddon AP, Goodwin DG, Haupt HM and Brooks JS: Phospho-S6 ribosomal protein: a potential new predictive sarcoma marker for targeted mTOR therapy. Mod Pathol 21: 231-237, 2008.
59. Kouvaraki MA, Liakou C, Paraschi A, Dimas K, Patsouris E, Tseleni-Balafouta S, Rassidakis GZ and Moraitis D: Activation of mTOR signaling in medullary and aggressive papillary thyroid carcinomas. Surgery 150: 1258-1265, 2011.

60. Villanueva A, Chiang DY, Newell P, Peix J, Thung S, Alsinet C Tovar V, Roayaie S, Minguez B, Sole M, et al: Pivotal role of mTOR signaling in hepatocellular carcinoma. Gastroenterology 135: 1972-1983, 1983 e1971-1911, 2008.

61. QianZR, Ter-Minassian M,Chan JA,Imamura Y,Hooshmand SM, Kuchiba A, Morikawa T, Brais LK, Daskalova A, Heafield R, et al: Prognostic significance of MTOR pathway component expression in neuroendocrine tumors. J Clin Oncol 31: 3418-3425, 2013.

62. Potratz JC, Saunders DN, Wai DH, Ng TL, McKinney SE, Carboni JM, Gottardis MM, Triche TJ, Jürgens H, Pollak MN, et al: Synthetic lethality screens reveal RPS6 and MST1R as modifiers of insulin-like growth factor- 1 receptor inhibitor activity in childhood sarcomas. Cancer Res 70: 8770-8781, 2010.

63. Khalaileh A, Dreazen A, Khatib A, Apel R, Swisa A, Kidess-Bassir N, Maitra A, Meyuhas O, Dor Y and Zamir G: Phosphorylation of ribosomal protein S6 attenuates DNA damage and tumor suppression during development of pancreatic cancer. Cancer Res 73: 1811-1820, 2013.

64. Dephoure N, Zhou C, Villén J, Beausoleil SA, Bakalarski CE, Elledge SJ and Gygi SP: A quantitative atlas of mitotic phosphorylation. Proc Natl Acad Sci USA 105: 10762-10767, 2008.

65. Olsen JV, Vermeulen M, Santamaria A, Kumar C, Miller ML, Jensen LJ, Gnad F, Cox J, Jensen TS, Nigg EA, et al: Quantitative phosphoproteomics reveals widespread full phosphorylation site occupancy during mitosis. Sci Signal 3: ra3, 2010.

66. Rigbolt KT, Prokhorova TA, Akimov V, Henningsen J, Johansen PT, Kratchmarova I, Kassem M, Mann M, Olsen JV and Blagoev B: System-wide temporal characterization of the proteome and phosphoproteome of human embryonic stem cell differentiation. Sci Signal 4: rs3, 2011

67. Roux PP, Shahbazian D, Vu H, Holz MK, Cohen MS, Taunton J, Sonenberg $\mathrm{N}$ and Blenis J: RAS/ERK signaling promotes site-specific ribosomal protein S6 phosphorylation via RSK and stimulates cap-dependent translation. J Biol Chem 282: 14056-14064, 2007.

68. Schläfli P, Tröger J, Eckhardt K, Borter E, Spielmann P and Wenger RH: Substrate preference and phosphatidylinositol monophosphate inhibition of the catalytic domain of the Per-Arnt-Sim domain kinase PASKIN. FEBS J 278: 1757-1768, 2011.

69. Stevens C, Lin Y, Harrison B, Burch L, Ridgway RA, Sansom O and Hupp T: Peptide combinatorial libraries identify TSC2 as a death-associated protein kinase (DAPK) death domain-binding protein and reveal a stimulatory role for DAPK in mTORC1 signaling. J Biol Chem 284: 334-344, 2009.

70. Falsone SF, Gesslbauer B, Tirk F, Piccinini AM and Kungl AJ: A proteomic snapshot of the human heat shock protein 90 interactome. FEBS Lett 579: 6350-6354, 2005.

71. Kim TS, Jang CY, Kim HD, Lee JY, Ahn BY and Kim J: Interaction of Hsp90 with ribosomal proteins protects from ubiquitination and proteasome-dependent degradation. Mol Biol Cell 17: 824-833, 2006.

72. Zou HY, Li Q, Lee JH, Arango ME, McDonnell SR, Yamazaki S, Koudriakova TB, Alton G, Cui JJ, Kung PP, et al: An orally available small-molecule inhibitor of c-Met, PF-2341066, exhibits cytoreductive antitumor efficacy through antiproliferative and antiangiogenic mechanisms. Cancer Res 67: 4408-4417, 2007.

73. Bonfils C, Beaulieu N, Fournel M, Ste-Croix H, Besterman JM and Maroun CR: The combination of MGCD265, a Met/VEGFR inhibitor in clinical development, and erlotinib potently inhibits tumor growth by altering multiple pathways including glycolysis. Cancer Res 72 (Suppl 8): S1790, 2012.

74. Qian F, Engst S, Yamaguchi K, Yu P, Won KA, Mock L, Lou T, Tan J, Li C, Tam D, et al: Inhibition of tumor cell growth, invasion, and metastasis by EXEL-2880 (XL880, GSK1363089), a novel inhibitor of HGF and VEGF receptor tyrosine kinases. Cancer Res 69: 8009-8016, 2009.

75. You WK, Sennino B, Williamson CW, Falcón B, Hashizume H, Yao LC, Aftab DT and McDonald DM: VEGF and c-Met blockade amplify angiogenesis inhibition in pancreatic islet cancer. Cancer Res 71: 4758-4768, 2011. 